\title{
A STUDY ON FUNDING AND FINANCIAL STRATEGY FOLLOWED BY WOMEN ENTREPRENEURS: A NEW WAY TO ENTREPRENEURIAL GROWTH OF BANGLADESH
}

\author{
Jesmin Ara \\ Assistant Professor \\ Department of Finance and Banking \\ Faculty of Business Studies \\ Hajee Mohammad Danesh Science and Technology University \\ Dinajpur-5200, Bangladesh \\ E-mail: jesmin.fib@tch.hstu.ac.bd
}

\begin{abstract}
Managing funds for venturing into a new business is a very challenging task for women. The goal of the study is to recognize congenial sources from where they can easily get funds to start their business and after starting a business which financial strategy they follow to expand their enterprise. To perform this task, primary data collection was carried out through a welldesigned questionnaire and a total of 180 women entrepreneurs from different parts of the country took part in this program spontaneously. It is observed that usually women do not get bank loans easily, but they discovered that semiformal and informal sources of funds are available for their business and these loans help them to achieve the entrepreneurial goal. Although the interest rate is much higher, to be self-employed women must collect funds from these sources. 77 percent of women withdraw profit and their business follows the start small and stay small characteristics, but others save and re-invest their profit to expand the business operation. Despite the great loss caused by the Covid-19 pandemic, it is a light of hope that some women are doing very well by using the digital platform and providing home delivery services. From this paper, the new women entrepreneur can perceive what should be done and they will go through the right way. By following former entrepreneurs, they should take the right decision and bring success assuredly.
\end{abstract}

Keywords: Bangladesh, Fund, Semiformal Source, Women Entrepreneur.

\section{INTRODUCTION}

The achievements of women for the progression of sustainable world economic development cannot be negated. To ensure economic growth, women-owned businesses are considered a vital measure. According to World Bank data 2020, Women are almost half $(49.4 \%)$ of the total population of Bangladesh. In the workforce of Bangladesh, women's participation is increasing day by day. But their involvement in business is not satisfactory. In Bangladesh women's participation in the business sector is very low. The percentage of women entrepreneur is lower than in our neighboring countries. According to a 2019 study by the IFC (International Finance Corporation), only 4.4 percent of businesses in Bangladesh are owned by women. But in 2016 the percentage was 7.2 percent. In recent time, due to Covid-19 crisis, many women unwillingly 
closed their businesses especially who were used physical location for providing services and doing business of immovable or difficult to moving products which could not be delivered by couriers. When at the same time many women move toward movable products businesses using a digital platform and delivery services. Women face many challenges in business, but the major challenge they face is limited funding. Because of the obvious inequalities, women entrepreneur's production-related activity was under-reflected so that they could not access desired capital (Brush, Greene, Balachandra, \& Davis, 2014).

Every business needs a start-up cost. Nowadays women can start a business with a very low amount of capital because they use the lower-cost digital platform for marketing and selling. By using an e-commerce platform, they do not need money for a well-decorated physical store or showroom. They only need inventory, warehouses, workers, some capital assets and so on. So, the amount of initial capital requirement is reduced. But still, this lower amount is not available to every women entrepreneur because most of them start a business as their first incomegenerating work. However, women-owned businesses are mostly small to medium-sized, and the capital requirement is not so large, the author wants to know why they cannot get funds easily.

Entrepreneurs either large or small are taking part to increase production as well as the GDP of any economy. Women start a business to meet their basic needs, but it contributes to the whole society and the economy of a country. In Bangladesh, women have many reasons for being an entrepreneur. As they are giving physical support and time to their family, it is difficult to maintain office hours for many women. Some women didn't get the expected job, or some remained unemployed. Some women want to help financially to their families. So, they start their own innovative small or medium business. The amount of this type of entrepreneur is not trivial. So, women entrepreneurs are a significant player in building a growing economy. When they want to start a business, in maximum cases their own capital is not sufficient to start a new business enterprise. They have to borrow funds from informal sources like family, friends, neighbors, relatives etc. or from some formal sources like financial institutions- banks, NGOs, and other formal providers. Women entrepreneurs should choose an appropriate combination of debt and equity capital otherwise they will not succeed in their business.

The objectives of the current study are

- To show which sources of fund are frequently used by female entrepreneurs and the study also reveal the terms of the fund.

- To seek whether women entrepreneurs reinvest their profit or withdraw it for personal expenses.

- To conclude the problems faced by women in collecting funds and to know whether the fund providers are considering these challenges.

In recent time due to the Covid-19 pandemic, many people lost their job, some got a partial salary. For lockdown situations, people pass the lazy time. So that many women are getting involved in small-scale businesses to give financial support to their families. They are thinking about the sources of financing. This study will help them to find an appropriate strategy for financing so that they can survive and achieve sustainable growth in their business. The purpose of this study is to serve the new woman entrepreneurs in the making decision about collecting funds to lever up the capital structure and gather handsome profit and sustainable growth. 


\section{LITERATURE REVIEW}

Several researchers' attention is given bellow

Ali and Rana (2016) presented a study based on women empowerment through the involvement of women of Rangpur region in operating parlor on the basis of sole proprietorship form. This study revealed that as Bangladesh is a developing country, women entrepreneur's faced different types of problems related to financial, social and ethical issues during the business operation. Going through the analysis based on both primary and secondary data this study mainly identified the problems of women entrepreneurs in conducting beauty parlor business in Bangladesh as well as prospects and possible opportunities towards women empowerment.

Chowdhury (2017) presented the pros and cons of entrepreneurial development in Bangladesh. Based on the secondary data this study mentioned the wide scope of entrepreneurship development in Bangladesh. Also this study points out the problems of mentality, efficiency, managerial, marketing, riskiness, infrastructural, technological, policymaking, political, international, corruption, inflation, the crisis of emergency fund, insufficient financial organization, complexity in loan granting, restrictive credit policy, unstable market structure, absence of proper policy decision, lack of proper financial support, lack of awareness of incentives provided by the government, lack of campaign about areas of entrepreneurship, lack of proper training facilities of entrepreneurs, lack of integrated package assistance, stimulating, supportive and sustaining activities needed for SMEs and so on.

Faruk, Hassan, and Islam (2016) reported that social entrepreneurship plays an important role in the socio-economic development of a country through solutions to social problems with the help of creating new ideas, developing social perception, and searching for new opportunities for the benefit of the society rather than private wealth maximization. This study aimed to identify the factors affecting the development of social entrepreneurship in Bangladesh as well some key factors to determine the development of entrepreneurial social business such as new opportunities and innovations, social welfare and value, leadership, knowledge, skill and experience, ability and willingness, funding and resources, etc.

Nyamwanza, Mapetere, Mavhiki, and Dzingirai (2012) identified business challenges faced by women entrepreneurs in implementing financial strategy. The study summarized that enterprise survival and growth were futile without appropriate financial management skills. Mwobobia (2012) listed the challenges facing small businesswomen in Kenya. The study identified that many stakeholders were trying to empower women entrepreneurs through the formation of funds for women entrepreneurs, formal and informal financial assistance and the donor's implementation. Witbooi and Ukpere (2011) dealt with the extent to which financial providers in South Africa were adequately aware of the challenges facing by women entrepreneurs. Abdullah, Johari, Bakri, and Razak (2015) descriptively analyzed the effectiveness of the collaboration between students and women entrepreneurs in Malaysia. The study found that the collaboration was very fruitful.

Chatterjee and Ramu (2018) found innovation and entrepreneurship were being dominated by women in India. The survey and round table interview were taken to trace out how innovation and entrepreneurship facilitated in India. Vladasel, Lindquist, Sol, and Praag (2020) analyzed the importance of family and community that affect entrepreneurship. They found that entrepreneurial careers could be highlighted at an early age.

Aggarwal, Goodell, and Selleck (2015) reported that microfinance institutions (MFIs) prefer women debtors universally for many reasons. The study aimed to attribute two major 
factors- the trustworthiness of women and the social impact of women. This study also depicted that microfinance institutions (MFIs) prefer women more in the low trust countries and interpreted gender targeting as an alternative for social belief.

Othman (2015) said women play a crucial role in attaining shared propensity via Islamic microfinance in Malaysia. This study also examined the effect of Islamic Microfinance to attain shared propensity and to boost up the economy. Researchers conducted many kinds of research on the influence of Islamic Microfinance to encourage comprehensive growth, hasten poverty reduction, and decline inequality. This study also aimed to discover the present effect of Islamic Microfinance on women entrepreneurs to attain shared propensity in Malaysia.

Murshid and Ball (2018) evaluated the link between women's physical mobility and participation of them in microfinance, empowerment program in Bangladesh based on the data from Bangladesh Demographic and Health Service of 2011. This study also discovered that women with physical mobility were 12 percentage to take part in microfinance paralleled to women without physical mobility. And there was a contradiction between the expansion of empowerment programs and cultural, patriarchal, social, infrastructural obstacles that precluded women from entering such programs.

D'Espallier, Guérin, and Mersland (2011) presented a study based on an international data set of 350 MFIs from 70 countries. The study explained that, in microfinance, the male borrower had more credit risks than the female borrower. It also stated that a greater number of female clients in microfinance related to fewer portfolio risks, fewer provisions and fewer write off. Besides, women related to higher repayment and resilience for NGOs, MFIs, and individualbased lenders.

Drori, Manos, Santacreu-Vasut, Shenkar, and Shoham (2018) discovered that the microfinance segment acknowledged and proceeded on inclusive markets as a relevant factor to promote female entrepreneurship. This study analyzed how organizations and institutional representatives smooth the method by which microfinance challenges gender-based financial segregation. This study confirmed market inclusion of women influenced by institutional and organizational factors based on the secondary data of 2361 microfinance institutions from 115 countries. Again Drori, Manos, Santacreu-Vasut, and Shoham (2020) explored gender targeting strategy of Microfinance Institutions (MFIs) was regulated by the role of culture. This study specified that there is a noteworthy effect of gender distinction on the targeting strategy of MIFs. This research also suggested to MFIs for distinguishing biased culture that can aid financiallyimpeded women. Fall, Tchuigoua, Vanhems, and Simar (2021) studied and assessed the effect of gender on the social competence of microfinance by applying nonparametric techniques to assess the influence of gender. They used 680 microfinance organizations as a cross-country database from six countries of the world. Their outcomes suggested that the mixture of gender had a positive influence universally on the social competence of microfinance.

Afroze, Alam, Akhter, and Jui (2014) worked on female entrepreneurs funding with other challenges and the determinant factors of entrepreneurship, the study area was the Khulna region of Bangladesh. It discussed available challenges like gender inequality, permission for doing business, inadequate capital negative perception, lack of training and technical support and so on. It found potential key success factors of women entrepreneurs were hard-working, family member's support, management and marketing skills, dedication etc.

From the above literature, it is visible that challenges of women entrepreneurship, societal and cultural factors related to women entrepreneurs were the subject matter of many studies. But it suggests a scarcity of evidence regarding funding problems and the financial 
strategy of women-owned businesses. Most of the previous research has been done using data of before the Covid-19 pandemic and has not found much impact of external factors that are salient in the recent phenomena.

\section{METHODOLOGY}

The study is based on originally collected primary data, but some secondary data is also used to mark the concurrent economic situation of Bangladesh. The respondents were women entrepreneurs that commenced business a minimum of one year ago. Primary data was collected from visiting women entrepreneurs personally. But due to the pandemic, a small number of data was collected over the phone. Data were collected from February to April of the year 2021 through interviews and surveys. A well-structured questionnaire was prepared which comprises both open and close-ended multiple-choice questions. At first, the questionnaire included some personal questions about the respondent's name, age, educational background etc. Businessoriented questions collected data about type, form, commencement, operation, location and so on. Financial information like the amount of capital, total assets, yearly sales, and profit was collected through the questionnaire. The main objective of the data collection was to gather data about funding and financial strategy followed by women entrepreneurs. All possible questions about funding and financial strategy were included in the questionnaire. Questions about the impact of Covid-19 in their entrepreneurial functions were also included. Respondents were also asked about limitations faced by them in operating business and the possible ways to solve these problems. They stated their future expectations with the hope of effective and prompt initiatives from the authority and the policymakers. In the time of face-to-face conversation, the author gathered some additional effective data beyond the questionnaire. These data were also analyzed and revealed in the result section of this study. Some attributes in the questionnaire were targeted to measure the entrepreneurs' perceptions by using a five-point scale (Highly dissatisfied, Dissatisfied, Neutral, Satisfied, Highly satisfied). 200 respondents from different regions of the country participated in this survey but from them, 20 respondent's questionnaires were rejected for partial answering.

Secondary data was collected from research papers, newspapers, magazines, journals and the internet. The nature of this study is descriptive and explanatory. Collected data was analyzed concluding some common statistical tools and techniques such as average, frequencies, percentage, pie chart and table for representing the chronicles. The researcher used SPSS software for data analysis.

\section{RESULT AND DISCUSSION}

Funding is the prerequisite for every business. In most cases, women entrepreneurs start small and stay small businesses. But this small amount is not available to the women because they are financially dependent on their parents or husband. Table 1 represents available sources of funds for women entrepreneurs. The study found that only 5 percent of women started their business with their own saved money. They saved money by cutting their expenditure or selling their assets. 11 percent of women collected their capital from family members, friends or relatives. This informal source was sometimes free of cost and sometimes very costly because some family members provide funds without charging any interest but some relatives or neighbors or friends charged higher interest rates. For funds, most entrepreneurs knocked on the door of semi-formal institutions or NGOs of our country. Women needed a small amount of loans, and these institutions provided microcredit, so the demand and supply sides matched each other. NGOs 
provided microcredit to beginners, so women entrepreneurs got loans easily from this source. Only well-established businesswomen were eligible for formal bank loans, so the percentage was very small which only 8 percent was. Although the starting capital was not so large, many women could not manage it easily. They tried to collect funds from multiple sources. When personal savings and informal loans were not enough, they move toward semi-formal or formal sources. This happened for 42 percent of women entrepreneurs who collected funds from more than one source.

Table 1. Women entrepreneur's sources of funds

\begin{tabular}{|c|c|c|}
\hline Sources of Fund & Frequency & Percentage \\
\hline Personal Savings & 8 & 4.5 \\
\hline $\begin{array}{c}\text { Informal (Family, Friends, } \\
\text { Relatives and Neighbors) }\end{array}$ & 18 & 10 \\
\hline Semi-formal (NGOs) & 60 & 33.3 \\
\hline Formal (Bank) & 14 & 7.7 \\
\hline More Than One Source & 80 & 44.5 \\
\hline Total & 180 & 100 \\
\hline
\end{tabular}

Source: Analysis of primary data (Feb-Apr) 2021

From 180 respondents only 10 percent could manage funds without any interest. Most of the entrepreneurs paid 11 to 13 percent interest to their borrowed fund. About 31 percent of women collected funds paying higher interest rates which were between 14 to 16 percent. Some fund provider offered lower interest rates 8-10 percent, but the number of these providers were very small. These results showed in Table 2.

Table 2. Women entrepreneur's cost of collecting fund

\begin{tabular}{|c|c|c|}
\hline Interest Rate $(\%)$ & Frequency & Percentage \\
\hline 0 & 18 & 10 \\
\hline $1-4$ & 0 & 0 \\
\hline $5-7$ & 1 & .6 \\
\hline $8-10$ & 10 & 5.5 \\
\hline $11-13$ & 95 & 52.8 \\
\hline $14-16$ & 56 & 31.1 \\
\hline Total & 180 & 100 \\
\hline
\end{tabular}

Source: Analysis of primary data (Feb-Apr) 2021

Table 2 represents 162 respondents who had to pay interest. The majority of these respondents were dissatisfied with the interest rate charged by the financial institutions. Table 3 represents the state of satisfaction with the interest rate of the women entrepreneurs. The satisfaction level was very low which indicated the interest rate was much higher for the women entrepreneurs. As they had no other choice, they took a loan at a higher interest rate to start their business. The author wanted to know the repayment rate with this unsatisfied interest rate. The 
interesting thing was that 98 percent of women borrowers paid their full loans. The common feature of these collateral-free loans was short-term and small amounts. Usually, loan installment frequency for the informal and semiformal institutions was weekly and for formal banks it was monthly. Data were collected from women entrepreneurs who had started a business minimum one year ago. For the short-term nature of the loan, all respondents paid their loan before they participated in the face-to-face interview.

Table 3. Women entrepreneur's level of satisfaction with the interest rate

\begin{tabular}{|l|l|l|}
\hline Level of Satisfaction & Frequency & Percentage \\
\hline Highly dissatisfied & 35 & 21.7 \\
\hline Dissatisfied & 72 & 44.4 \\
\hline Neutral & 43 & 26.5 \\
\hline Satisfied & 12 & 7.4 \\
\hline Highly satisfied & 0 & 0 \\
\hline Total & 162 & 100 \\
\hline
\end{tabular}

Source: Analysis of primary data (Feb-Apr) 2021

The fund was inevitable for any business whether it is small or large. The utilization of available funds is also a very challenging task for the entrepreneur. Women usually like to do that business in which they have much knowledge or expertise. So that they can easily earn profit. As the maximum women owner operate small to medium business, they manage business by their self. Sometimes they get help from family members and recruit few numbers of employees. The study found that, before the Covid-19 pandemic all women could earn profit but after starting the pandemic, the profitability position had been changed. Many women faced losses in their business. The profitability of every business got volatile because of the lock-down situation. But results showed that e-commerce-based businesses' profits were increased. The study also found about 97 percent of the entrepreneurs operated their business in urban areas. There were many facilities they received in the urban areas which were not available in the rural areas. Communication facilities, infrastructural facilities, network facility and product delivery facilities were inevitable for women entrepreneurs. Table 4 shows the direction of profitability in the Covid-19 crisis.

Table 4. Women entrepreneur's direction of profitability due to Covid-19 pandemic

\begin{tabular}{|l|l|l|l|l|}
\hline $\begin{array}{l}\text { Method of } \\
\text { operation }\end{array}$ & Profitability & $\begin{array}{l}\text { Business } \\
\text { orientation }\end{array}$ & Frequency & Percentage \\
\hline $\begin{array}{l}\text { Physical } \\
\text { location-based }\end{array}$ & Highly decreased & Product & 4 & 2.2 \\
\cline { 2 - 5 } & Service & 68 & 37.8 \\
\cline { 2 - 5 } & \multirow{2}{*}{ Decreased } & Product & 0 & 0 \\
\cline { 2 - 5 } & Stable & Service & 32 & 17.8 \\
\cline { 2 - 5 } & & Product & 1 & 0.6 \\
\cline { 2 - 5 } & Service & 1 & 0.6 \\
\hline Digital platform- & Increased & Product & 63 & 35 \\
\hline
\end{tabular}




\begin{tabular}{|l|l|l|r|r|}
\hline based & & Service & 0 & 0 \\
& & & 11 & 6 \\
\cline { 3 - 5 } & Highly increased & Product & 0 & 0 \\
\cline { 3 - 5 } & & Service & 180 & 100 \\
\hline Total & & \multicolumn{3}{|l|}{} \\
\hline
\end{tabular}

Source: Analysis of primary data (Feb-Apr) 2021

The study also tried to know the loan recovery consideration by the loan providers during the period of lockdown. More than 90 percent of the respondents said that the lenders' consideration for loan repayment in the lockdown situation was good to excellent. From the borrower's point of view, as their income slowed down this consideration was very helpful for their survival. According to the Microcredit Regulatory Authority's circular letter54, 25 March 2020, microfinance institutions cannot force the borrower to pay the installment if he or she was financially disabled. However, some respondents said that the loan consideration was poor to fair, but these types of cases were below 5 percent. It was known that some entrepreneurs took a loan from informal sectors, and it caused this miserable situation.

Women entrepreneurs followed two strategies about the uses of the earned profit. Either they withdrew the profit, or they retained it in the business. Table 5 represents the result of the uses of profit followed by women entrepreneurs. 77 percent of the respondents withdrawn their profit because the business was the main source of their income. Some entrepreneur (11\%) reinvested their profit because they want to expand their assets and some of them followed both strategies to run their business in the long run. The study found that as they spend the withdrawn money, 80 percent of entrepreneurs wanted to take a further loan to expand their business. Some respondents said to the author that they withdraw money and saved it so that they can use it in their financial crisis or when they need more capital to increase their business operation.

Table 5. Women entrepreneur's utilization of profit

\begin{tabular}{|l|l|l|}
\hline Uses of profit & Frequency & Percentage \\
\hline Re-invest & 20 & 11.1 \\
\hline Withdraw & 140 & 77.8 \\
\hline Both & 20 & 11.1 \\
\hline Total & 180 & 100 \\
\hline
\end{tabular}

Source: Analysis of primary data (Feb-Apr) 2021

Apart from the funding and financial strategy of women entrepreneurs, the current study got some other important information. Some of them are highlighted to give a better understanding of the features of women's entrepreneurship. If we see the result depicted in table 6 , day by day the number of women entrepreneurs is increasing. The possible reason was for the Covid-19 pandemic many families become helpless and both males and females started ecommerce-based businesses. Because of the lockdown situation online selling has become popular and feasible everywhere. When the author collected data, she found that many women entrepreneurs were studying at graduation and post-graduation levels of many renowned universities of our country. They utilized their leisure time to financially support their family. 
Table 6. Women entrepreneur's duration of businesses

\begin{tabular}{|l|l|l|}
\hline $\begin{array}{l}\text { Duration of Business } \\
\text { (years) }\end{array}$ & Frequency & Percentage \\
\hline $1-2$ & 57 & 31.7 \\
\hline $3-4$ & 69 & 38.3 \\
\hline $5-6$ & 30 & 16.7 \\
\hline $7-8$ & 10 & 5.6 \\
\hline $9-10$ & 6 & 3.3 \\
\hline $10+$ & 8 & 4.4 \\
\hline Total & 180 & 100 \\
\hline
\end{tabular}

Source: Analysis of primary data (Feb-Apr) 2021

Some demographic factors (age, education and marital status) are pictured below
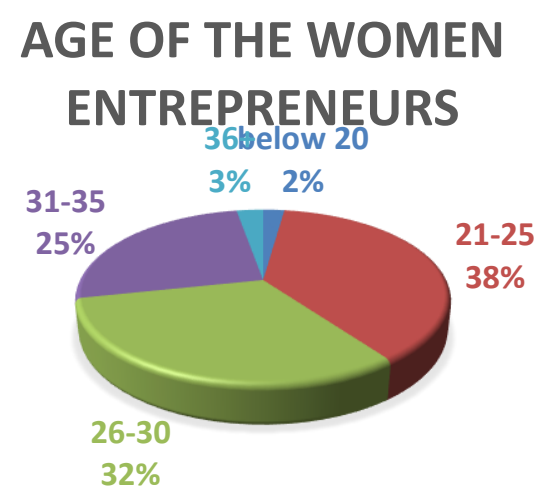

Figure 1. women entrepreneur's age

Above figure mention that 38 percent of the women entrepreneurs belonged to 21 to 25 years and 32 percent of them were between 26 to 30 . Women had started their businesses in the early stage of their life. Some women left their job for many reasons. They found a new way which was an alternative to do a job. Entrepreneurship brought them self-independent.

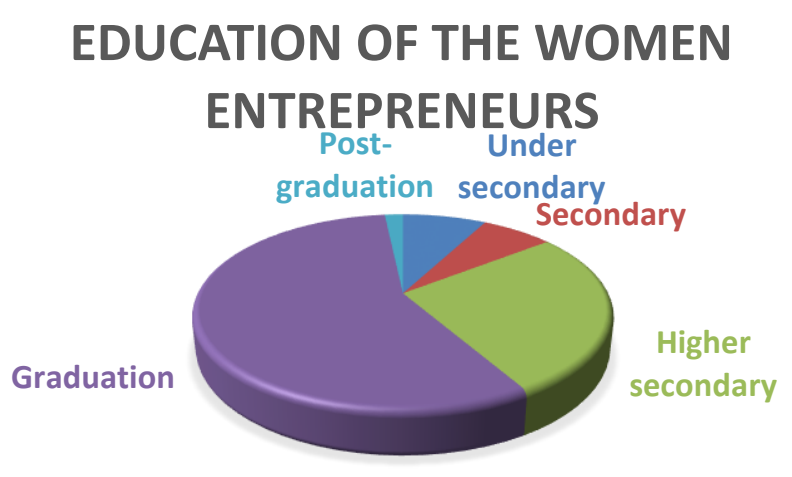

Figure 2. Women entrepreneur's level of education 
The above figure represents the level of education of the entrepreneurs. As we observed that most of the entrepreneurs' age were 21 to 35 and they started business from 1 to six years ago, so the level of education was obviously higher secondary to graduation. The result explains that educated women were interested to do business and wanted to prove their capability of doing business. It is a good sign for our economic and social capital development. Women entrepreneurs are taking part in the growth of our country's GDP and solve the unemployment problem. The study also finds that the women were educated but they did not have technical knowledge about how to operate businesses as well as they need specific sectoral training to upgrade the business position. Women entrepreneurs demanded a higher level of training and incentives from the government.

Of the female respondents, 59 percent were married and 40 percent were unmarried. The study found only one percent divorcee. The study also discovers the ownership format of the respondents. The result shows that 98 percent women were sole proprietor and 2 percent were doing as a partner. 42 percent of the respondent were operating their business by using an ecommerce platform and 58 percent had a physical location, store or showroom to provide products and services manually. Again, 83 percent of women did not get insurance for their business.

In the environmental sustainability issue, women were very conscious. They claimed that their work did not hamper the environment in any way. Doing business by themselves did not threaten the environment by emitting any pollutants to society. The greater portion of the entrepreneurs used eco-friendly products.

There are many problems with women's entrepreneurship. Experiencing domestic violence is one of them. Physical violence by husbands influences women entrepreneur's decision to initiate a new business when they have access to financing (Shahriar \& Shepherd, 2019). From the analyzed result, 11 women entrepreneurs had gone through physical violence and they said that this violence negatively affects their entrepreneurial initiatives. 20 percent women believed that the society exhibited negativity to accept women as an entrepreneur.

Key problems of women entrepreneurs identified by the author were lack of funds, lack of knowledge and training, family restriction, unfavorable business environment, balancing between family and business, network problem, women security, unavailable formal loan and so on. Most of the women wanted formal financial institutions loans with lower interest rates and ease of formalities in getting a loan. Women were less likely to obtain a bank loan and if women got a bank loan, they must pay a higher rate of interest than male entrepreneurs (Muravyev, Talavera, \& Schäfer, 2009). Women entrepreneurs wanted microfinance institutions to increase the installment duration so that they got enough time to manage money for the loan repayment. They also wanted to gather practical knowledge through higher-level training. Women entrepreneurs said that in the job sector women got many privileges but in the business sector they didn't get any subsidies or incentives. So, most of the women entrepreneurs placed a request to the government to grant incentives and subsidies for their business development.

\section{CONCLUSION}

The establishment of women's entrepreneurship has a positive influence to increase the living standard of their family and society. Major challenges that women entrepreneurs face in doing business are limited funding, balancing business with family life, fear of failure, gender inequality and an unfavorable business environment. By considering these challenges the study aims to help them to find the appropriate strategy for financing and making decisions about 
collecting and using funds. It will help them to survive and achieve sustainable growth in their business. Male-dominated societies do not believe in the capability of women. Women entrepreneurs do not get loans easily from formal financial institutions like male entrepreneurs. Formal financial institutions have many criteria for loan approval and have some limitations in managerial decisions. So, women entrepreneurs relied on semiformal NGOs and informal sources like family members and friends. Although women are capable to repay the loan with a higher interest rate, the interest rate is not satisfactory to them. For the betterment of women as well as the whole economy the MIFs should minimize the interest rate.

Women made a choice of doing business to provide financial backing to their families. Most of the female entrepreneurs withdraw their business profit because it is the only accessible source of income in front of them. Some entrepreneur has other sources of income, so they retain their profit for future investment requirements.

As the study was conducted at the time of the Covid-19 pandemic, the study cannot get the expected number of respondents. Lack of having contact numbers, it was not possible to communicate with many women entrepreneurs. One of the major challenges of data collection was to collect financial data because most women did not record proper financial statements. Sometimes they gave an estimated amount and sometimes gave the wrong financial figure. For this reason, the study cannot analyze financial factors. The study considers only the available avenue of funds like banks, NGOs, family, and friends but nowadays, crowdfunding offers an innovative funding source for both male and female entrepreneurs of the world. In the recent future, crowdfunding could be a lucrative source of funds for the women entrepreneurs of Bangladesh. In the future, researchers could consider this source of funds also.

\section{REFERENCES}

Abdullah, J., Johari, H. S. Y., Bakri, A. A., \& Razak, W. M. W. A. (2015). Students and Women Entrepreneurs' Collaborations in Social Entreprise Program at UiTM, Malaysia. Procedia-Social and Behavioral Sciences, 168, 97-103. https://doi.org/10.1016/j.sbspro.2014.10.214

Afroze, T., Alam, M. K., Akther, E., \& Jui, N. S. (2014). Women entrepreneurs in Bangladesh Challenges and determining factors. Journal of Business and Technology (Dhaka), 9(2), 27-41.

Aggarwal, R., Goodell, J. W., \& Selleck, L. J. (2015). Lending to women in microfinance: Role of social trust. International Business Review, 24(1), 55-65. https://doi.org/10.1016/j.ibusrev.2014.05.008

Ali, M. J., \& Rana, M. M. (2016). Women entrepreneurship of Bangladesh: A contextual study on beauty parlor business of Rangpur expanse. International Journal of Business and Economics Research, 5(3), 61-70.

Brush, C., Greene, P., Balachandra, L., \& Davis, A. (2018). The Gender Gap in Venture Capital- Progress, Problems, and Perspectives. An International Journal of Entrepreneurial Finance, 20(2), 115-136. 
Chatterjee, C., \& Ramu, S. (2018). Gender and its Rising Role in Modern Indian Innovation and $\begin{array}{llll}\text { Entrepreneurship. } \quad \text { IIMB } & \text { Management }\end{array}$ https://doi.org/10.1016/j.iimb.2017.11.006

Chowdhury, F. N. (2017). A Study of Entrepreneurship Development in Bangladesh: Pros and Cons. Journal of Asian Scientific Research, 7(1), 1-11.

D’Espallier, B., Guérin, I., \& Mersland, R. (2011). Women and Repayment in Microfinance: A Global Analysis. World Development, 39(5), 758-772. https ://doi.org/10.1016/j.worlddev.2010.10.008

Drori, I., Manos, R., Santacreu-Vasut, E., Shenkar, O., \& Shoham, A. (2018). Language and Market Inclusivity for Women Entrepreneurship: the Case of Microfinance. Journal of Business Venturing, 33(4), 395-415. https://doi.org/10.1016/j.jbusvent.2018.02.002

Drori, I., Manos, R., Santacreu-Vasut, E., \& Shoham, A. (2020). How Does the Global Microfinance Industry Determine its Targeting Strategy Across Cultures with Differing Gender Values? Journal of World Business, 55(5), 100985, https://doi.org/10.1016/j.jwb.2019.02.004

Fall, F.S., Tchuigoua, H. T., Vanhems, A., \& Simar, L. (2021). Gender Effect on Microfinance Social Efficiency: A Robust Nonparametric Approach. European Journal of Operational Research, 295(2), 744-757. https://doi.org/10.1016/j.ejor.2021.03.020

Faruk, M. O., Hassan, N., \& Islam, N. (2016). Factors Influencing the Development of Social Entrepreneurship in Bangladesh. http://dx.doi.org/10.2139/ssrn.2856210

Muravyev, A., Talavera, O., \& Schäfer, D. (2009). Entrepreneurs' Gender and Financial Constraints: Evidence from International Data. Journal of Comparative Economics, 37 , 270-286. https://doi:10.1016/j.jce.2008.12.001

Murshid, N. S., \& Ball, A. (2018). Examining Women's Physical Mobility and Microfinance Participation in Bangladesh: Results from a Nationally Representative Sample. Women's Studies International Forum, 69, 33-39, https://doi.org/10.1016/j.wsif.2018.04.009

Mwobobia, F. M. (2012). The Challenges Facing Small-Scale Women Entrepreneurs: A Case of Kenya. International Journal of Business Administration, 3(2), 112-121. http://dx.doi.org/10.5430/ijba.v3n2p112

Nyamwanza, T., Mapetere, D., Mavhiki, S., \& Dzingirai, C. (2012). Financial Management: Case Study of Gweru Women Entrepreneurs. International Journal of Business and Social Science, 3(18), 99-106.

Othman, M. B. (2015). Role of Women in Achieving Shared Prosperity: An Impact Study of Islamic Microfinance in Malaysia. Procedia - Social and Behavioral Sciences, 211, 1043-1048. https://doi.org/10.1016/j.sbspro.2015.11.139 
Shahriar, A. Z. M., \& Shepherd, A. (2019). Violence against Women and New Venture Initiation with Microcredit: Self-efficacy, Fear of Failure, and Disaster Experiences. Journal of Business Venturing, 34(6), 105945.

Vladasel, T., Lindquist, M. J., Sol, J., \& Praag, M. V. (2020). On the Origins of Entrepreneurship: Evidence from Sibling Correlations. Journal of Business Venturing. https://doi.org/10.1016/j.jbusvent.2020.106017

Witbooi, M., \& Ukpere, W. (2011). Indigenous Female Entrepreneurship: Analytical Study on Access to Finance for Women Entrepreneurs in South Africa. African Journal of Business Management, 5(14), 5646-5657. https://doi.org/10.5897/AJBM10.1161

\section{Copyrights}

Copyright for this article is retained by the author(s), with first publication rights granted to the journal. This is an open-access article distributed under the terms and conditions of the Creative Commons Attribution license (http://creativecommons.org/licenses/by/4.0) 